\title{
An Evaluation of the Effects of Work Stress, Work Load and Work Environment on Employee's Turnover: The Role of Job Satisfaction
}

\author{
Prahyudi Apriyanto Siswoyo Haryono* \\ Ph.D. in Management Postgraduate Program, Universitas Muhammadiyah Yogyakarta \\ Jl. Brawijaya, Tamantirto, Kasihan, Bantul, Yogyakarta 55183, Indonesia
}

\begin{abstract}
Turnover Intention in the present study is a situation where the employee leaves the company due to disturbance in operation, teamwork dynamics, and unit performance of PT. Patria Migas. This study aims to determine the direct effects of work stress, workload, work environment on turnover intentions, and the effects of work stress, workload, work environment on turnover through job satisfaction as a mediating variable. The subjects in this study are employees of PT. Patria Migas, with a total of 48 respondents. The model in the study was tested using Structural Equation Model (SEM) data analysis technique with Partial Least Square (PLS) and using software Smart-PLS 3.0. The result of the study indicates positive and significant effects both directly on work stress, workload, and work environment on turnover intentions, and mediation of work stress, workload, and work environment turnover intentions mediated by job satisfaction. This study aims to add insight on turnover intentions and variables such as work stress, workload, work environment an job satisfaction which can create a turnover
\end{abstract}

Keywords: work stress, workload, work environment, job satisfaction, and turnover intentions

DOI: $10.7176 / \mathrm{JRDM} / 64-03$

Publication date: April $30^{\text {th }} 2020$

\section{Introduction}

The existence of human resources in an organization plays a significant role. The workforce has excellent potential to carry out organizational activities. The potential of every human resource in an organization must be able to provide optimal output. The achievement of organizational goals does not only depend on modern equipment, complete facilities, and infrastructure but rather depends more on the people who carry out the work (Noe et al., 2017).

Turnover Intention of an individual is an adverse

Aamodt

impact of the inability of an organization to manage individual behavior. Employee turnover is generally a negative issue for the company but can be a real issue if controlled appropriately and logically. Turnover is often used as an indicator of company performance and is easily perceived negatively as a result of the company's effective efficiency policy. Many factors make the turnover of employees in an organization becomes high, in whom is the work environment and work stress. In connection with the emergence of Turnover Intention, employees who have job satisfaction will be more productive, contribute to the goals and objectives of the organization, and generally have a low desire to leave the company. Dissatisfaction can lead to undesirable work outcomes such as theft, finding part-time work, and can lead to absenteeism and consider opportunities to find other jobs (Harter et al., 2002).

Work stress factors can influence turnover. There are many studies regarding employee work stress. Robbins and Judge (2018) define stress as a dynamic condition in which individuals face opportunities, constraints, or demands related to what they want and whose results are as uncertain but essential. Schuler (2017) suggested that there are "4S" common causes of stress for many workers are Supervisors (superiors), Salary (salaries), Security (safety), and Safety (safety). The rules of work are narrow, and pressures are high is a significant cause of stress. Salaries can be a cause of stress if they are not fair. Workers can also experience stress when feeling uncertain in a relationship with worker safety. For many workers, low job security can cause stress. Fear of workplace accidents and injuries and the threat of death can also be stressful.

Workload factors also influence turnover. Robbins (2018) states that positive and negative workload is a matter of perception. Perception is a process by which individuals organize and interpret their sensory impressions to give meaning to their environment. Different factors in the work environment, such as wages, working hours, autonomy to employees, organizational structure, and communication between employees and management, can influence job satisfaction (Applebaum et al. 2010).

Job satisfaction is interpreted as a person's general attitude towards his job or can also e interpreted as the difference between the amount of rewards/awards received by employees and the amount they should get (Robbins, 2018). According to Colquit et al. (2017), job satisfaction is a positive and pleasant emotional state 
that results from an assessment of work or work experience. From the description above, some factors affect turnover. Each company needs to retain every employee to work in the company. Some research on the Effect of Job Stress, Workload, and Work Environment on job satisfaction shows that al variables have an impact on Turnover Intention.

\section{Literature Review}

\subsection{Turnover Intention}

Turnover Intention is the tendency or intention of employees to stop working from work. (Harnoto in Widjaja, et al., 2008). According to Mathis and Jackson (2016), turnover is the level of employee turnover that occurs when employees leave the organization. Lussier and Hendon (2019) turnover, is the discharge of employees from companies to work in other companies. According to Halimah et al. (2016), Turnover Intention measurement indicators consist of: (1) thinking about getting out. Reflect individuals to think out of work or remain in the work environment, and (2) alternative search for work. Reflecting the individual desires to find work in another organization. High and low Turnover Intention will have an impact on employees and the company. The impact of Turnover Intention is a). workload. If employee turnover intentions are high, the workload of employees increases because the number of employees decreases. b). Costs for employee withdrawals concerning time and facilities for interviews in the employee selection process, withdrawals, and studying the replacement of resigned employees. c). Training costs, if Turnover Intention is high and many employees leave the organization, this will increase employee training costs. d). Production lost during employee turnover. e). Much waste due to new employees, and e). Triggering employee stress. Employee stress can occur because old employees must adapt to new employees. The worst effect of this stress is triggering employees who live to desire to leave the company.

\subsection{Job Stress}

Job stress, according to Rivai (2005) a condition of tension that creates a physical and psychological imbalance that affects emotions thought processes and the condition of an employee. According to Oentoro et al. (2006), work stress is a condition of tension that occurs because of pressures and difficulties in work that exceed the standard threshold and are accompanied by a lack of support from various parties. Whereas Aamodt (2017) stated that work stress is a condition where there are one or several factors in the workplace that interact with workers so that it disrupts physiological and behavioral conditions. Job stress will arise if there is a gap between an individual's abilities and the demands of his job. Job stress is a gap between individual needs and their fulfillment from the environment. Stress will arise if the demands of the work e not balanced with the ability to meet these demands, giving rise to various levels of work stratification and high levels.

\subsection{Workload}

According to Anita, et al. (2013) workload is several activities that must be completed systematically by an organizational unit/position holder using job analysis techniques, workload analysis techniques / other management techniques within a specified period to obtain information about work efficiency and effectiveness of an organizational unit. The workload is the amount of work that is assumed by employees or work units in an organization within a specified period (Febriyanti and Faslah, 2013).

Afia (2013) defines workload as several task demands, which usually have a considerable time constraint in which there are three aspects. First, the amount of work and the number of things that have to do by employees.ne. Second, aspects of time and subjective experience of employees, are assumed if the workload increases, the error rate also increases. Third, the mental and physical effort that an employee uses reflects an employee's response to his duties.

According to Anita et al. (2013), the workload is several activities that must be completed by an organizational unit or position holder systematically using job analysis techniques, workload analysis techniques, or other management techniques within a specified period to obtain information about work efficiency and effectiveness of an organizational unit.

\subsection{Work environment}

According to Gibson (2012), work are all factors of physical, psychological, social, and networking relations prevailing in the organization and affect the employees. The work environment is an environment that involves all factors, both physical and social, which also influence one's work. According to Heizer et al. (2020), the work environment is an environment where the workers work, while the conditions in which the workforce works. The work environment is everything that exists around the workforce in the form of both the physical and psychological environment that can affect the workforce or the teacher in carrying out his work duties. The work environment in an organization has an essential meaning for humans who carry out activities in it because this work environment will affect directly or indirectly on humans in it.

Dessler (2017 ) emphasized that the work environment is the overall tools and burdens faced, the 
surrounding environment in which a person works, his work methods, and work arrangements both as individuals and as groups. The factors that could affect the work environment include (1) illumination/lighting, (2) the temperature of the air/oxygen, (3) noise, (4) job security, and (5) the relationship between employees.

\subsection{Job satisfaction}

Job satisfaction is a security feeling or feeling of security. Job satisfaction has socio-economic aspects such as salary and social security, as well as social-psychological aspects which include: opportunities to advance, opportunities to get awards, dealing with supervisory issues, as well as dealing with relationships between employees and employees, and between employees and their superiors (Aamodt, 2010). According to Sunyoto (2001), job satisfaction is the overall result of the degree of liking or dislikes employees for various aspects of their work. In other words, job satisfaction shows the attitude of employees towards their work. Job satisfaction is a general attitude towards one's work, the difference between the amount of reward received by an employee and the amount they believe in, and what they should receive (Robbins, 2015).

Champoux (2017) mention; elements of job satisfaction include (1) relationships with colleagues; (2) relationship with the leadership; (3 ) capability and efficiency of department heads; (4) hours of work; (5) ability to take the initiative; (6) Promotion chance; (7 ) g aji; (8 ) security wheel work; (9) work s; and (10) work. While Luthans (2006) t satisfaction, here are five dimensions of job satisfaction, namely: (1) the work itself, (2) salary/salary, (3) opportunities for advancement or promotion, (4) supervision, and (5) workmate.

\section{Hypothesis Development}

Lestari (2018) states that work stress can affect turnover intention; many factors affect turnover intention, including work stress, organizational commitment, and job satisfaction. One of the causes of employee desires to leave the company is work stress. Work stress is something that involves the interaction between individuals and the environment that is the interaction between stimulation and response. Job stress is a consequence of every action and environmental situation that causes excessive psychological and physical guidance to someone (Sunyoto, 2015).

$\mathrm{H}$ 1: There is an influence of work stress on Turnover Intention at PT Patria Migas.

Excessive workload will cause physical and mental fatigue and can cause emotional reactions such as headaches, indigestion, and irritability. Conversely, too little workload with a monotonous routine will lead to boredom. Boredom in routine daily work due to too little assignment or work results in a lack of attention to work that can potentially endanger workers (Haryono et al. 2019).

H2: There is an influence of workload on Turnover Intention at PT Patria Migas.

The work environment has a negative influence on turnover intention, where when the work environment in a company is not conducive to work such as adequate lighting or light and guaranteed workplace security, it is inevitable that employees will not last long in the company and it can be said turnover intention will be higher (Joarder et al., 2011; Applebaum and Fowler, 2010). The work environment has a negative influence on turnover intention, a bad work environment, such as the lack of facilities received by employees, there is no place for employees to rest, will encourage employee intentions to resign.

H3: There is a negative influence of the work environment on Turnover Intention at PT Patria Migas.

Work stress in the work environment also affects emotions, employee job satisfaction, which ultimately arises the decision to quit from work. The higher job stress experienced by employees, the job satisfaction perceived will decrease; this is what causes the desire of employees to quit the company. (Indrayani, 2012)Basri (2017). Likewise, a study by Dewi, which said that to reduce turnover intention, the hospital must be able to control the level of employee work stress by paying attention to the workload provided with individual work capacity and also the time given in completing work. The hospital scheduled to give awards to employees who have done their job well (Dewi, 2019).

H4: There is an influence of work stress on Turnover Intention, which is mediated by job satisfaction at PT Patria Migas.

Research by Pradana proves that two factors cause the workload at a high value that is related to the number of jobs they do and work time. Between these two things, work time is the most burdensome for employees. They are required to work long hours, overtime, even on vacation. Of course, this is very burdening employees because they also need time to rest and personal time to balance their lifestyle. Besides, there are salary factors as well as fatigue and health factors, which are factors that they feel are not yet satisfying for them. Then the fatigue felt after work becomes the most stressing factor for their work. Pradana (2013).

H5: There is an influence of workload on Turnover Intention, which is mediated by job satisfaction at PT Patria Migas.

Job satisfaction is one of the factors that are considered by employees to work for one company. Job satisfaction is individual so that the job satisfaction of an employee will be different from other employees (Rusdiyanto, 2015). An employee who is dissatisfied with his job tends to look for another place of work, with 
the hope that the new workplace can meet his satisfaction. (Yuda, 2017). One of the things that are most felt by employees in carrying out daily operational activities is their work environment. A comfortable and conducive work environment is a dream for employees so that employees can carry out their activities optimally, safely, and comfortably (Widhiastana, 2017).

H6: There is an influence of the work environment on Turnover Intention mediated by job satisfaction at PT Patria Migas.

\section{Research Methodology}

This research is quantitative. Sekaran (2016) argues that quantitative research is research based on the philosophy of positivism, used to examine specific populations or samples, sampling techniques randomly, data collection uses research instruments, data analysis is statistical quantitative in order to test hypotheses.

The analytical tool used in this study is Partial Least Square (PLS). Partial Least Square (PLS) is a powerful analysis method because it does not assume the data must be of a specific scale measurement, the number of samples is small. PLS can help researchers to get the value of latent variables for predictive purposes. The formal model defines latent variables as linear aggregates of the indicators. Estimation results in PLS can be three categories, namely the weight estimate used to create a latent variable score, the path estimation used by latent variables and between variables and indicator blocks, and related to means and location parameters (regression constant values) for Imam indicators and latent variables Ghozali (2006). This research aim determines the effect of work stress, workload, work environment on job satisfaction, which has an impact on Turnover Intention at PT Patria Migas.

\subsection{Variable Identification}

Variable $\mathrm{s}$ tres $\mathrm{k}$ Work $\mathrm{w}$ in this study is the condition of the tension on the employee because of pressures and difficulties in the work and with the lack of support from various parties in PT. Patria Migas. The work variables in this study are several activities that must be completed by the employees of PT. Patria Migas systematically, by the duties of each section, to obtain sufficient and efficient work. The work environment variable in this study is an environment that involves all factors, both physical and social, which also influence the work of PT. Patria Migas.ms The job satisfaction is the satisfaction of employees both in terms of economic, social psychology, and the relationship between fellow employees or the relationship with the supervisor of PT. Patria Migas. While the variable Turnover Intention in this study is a situation where employees leave the company caused by disruptions in operations, teamwork dynamics, and the performance of PT. Patria Migas.

\section{Results and Discussion}

\subsection{Data Analysis}

Data analysis techniques used in this study were descriptive statistical analysis and Partial Least Square (PLS) using the SmartPLS 3.0 software program. Descriptive data analysis techniques are statistics to analyze data by describing or describing data without intending to make generally accepted conclusions or generalizations (Haryono, 2017). The analytical method used is Partial Least Square (PLS). PLS is a Structural Equation Modeling (SEM) technique that can analyze latent variables, indicator variables, and measurement errors directly. PLS can be used with a small number of samples and can e applied at all data scales.

\subsection{Validity and Reliability}

In this examination, the instrument testing s done by testing the validity and reliability. Validity test is done by (1) Convergent Validity test, expected value $>$ 0.7. However, according to Chin, 1998 (in Ghozali, 2015), for the initial stages of research, the development of a measurement scale of loading values 0.5 to 0.6 was considered sufficient. In this research, a loading factor limit is 0.50 .ed. (2) Discriminant Validity test by comparing the loading value of the intended variable must be greater than the loading value with other variables. (3) Average Variance Extracted (AVE), expected AVE value $>0.5$. The reliability test in the study was using a composite reliability test, said to be reliable if it has a composite reliability value $\geq 0.7$. Validity and reliability tests were processed using SmartPls 3.0.

\subsection{Hypothesis Testing}

Hypothesis testing was using the Structural Equation Modeling model with the Partial Least Square technique to test the effect of each variable of work stress, workload, work environment, job satisfaction, and Turnover Intention. Furthermore, hypothesis testing uses the level of significance of the path coefficient obtained from the $\mathrm{t}$-statistic value and the value of the standardized path coefficient. The limit of the hypothesis testing value is the loading factor, which is greater than the critical value $(>1.96)$. The results of the analysis of the research model are as follows: 


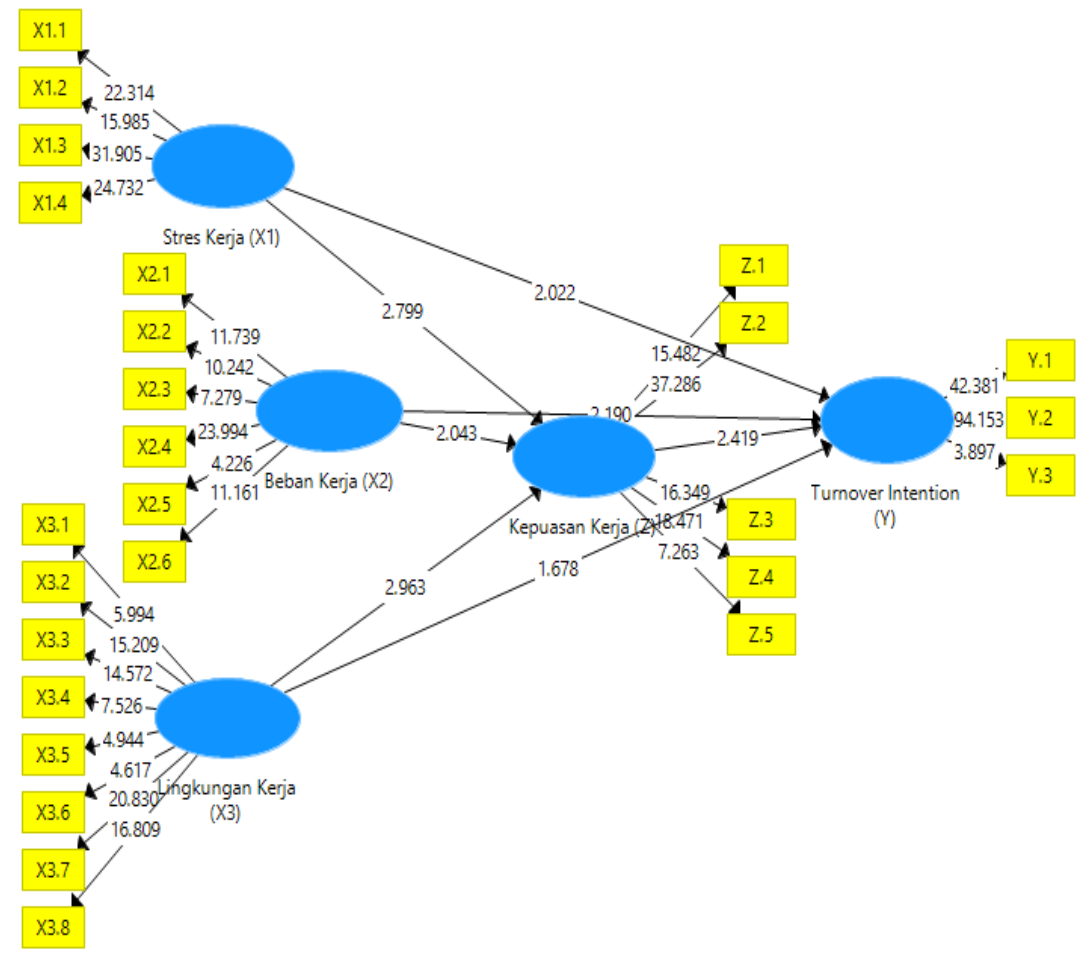

Figure 2. Results of research analysis with PLS

Table 1. Direct Effect Testing Results

\begin{tabular}{|c|l|c|c|c|}
\hline No & \multicolumn{1}{|c|}{ Direct Influence } & Coefficient Value & T count & $P$ value \\
\hline 1 & Job Stress -> Job Satisfaction & $-0,250$ & 2,799 & 0.003 \\
\hline 2 & Workload -> Job Satisfaction & $-0,283$ & 2,043 & 0.021 \\
\hline 3 & Work Environment -> Job Satisfaction & 0.411 & 2,963 & 0.002 \\
\hline 4 & Job Satisfaction -> Turnover Intention & -0.360 & 2,419 & 0.008 \\
\hline 5 & Job Stress -> Turnover Intention & 0.220 & 2,022 & 0.022 \\
\hline 6 & Workload -> Turnover Intention & 0.216 & 2,190 & 0.014 \\
\hline 7 & Work Environment -> Turnover Intention & $-0,187$ & 1,678 & 0.047 \\
\hline
\end{tabular}

Source: SmartPLS output, processed by researchers

Table 2. Indirect Effects Test Results

\begin{tabular}{|c|l|c|c|c|}
\hline No & \multicolumn{1}{|c|}{ Indirect Influence } & Coefficient Value & T count & P-value \\
\hline 1 & Job Stress -> Turnover Intention & 0.090 & 1,810 & 0.035 \\
\hline 2 & Workload -> Turnover Intention & .102 & 1,714 & 0.044 \\
\hline 3 & Work Environment -> Turnover Intention & $-0,148$ & 1,815 & 0.035 \\
\hline
\end{tabular}

Source: SmartPLS output, processed by researchers

\subsection{Discussion}

The results of hypothesis testing (H1) prove that there is an influence of work stress on turnover intention. A coefficient of 0.220 with a $p$-value of 0.022 . Therefore $0.022<0.05$, Ha is accepted. This test statistically proves that work stress has a positive effect on turnover intention. The results of this study are in line with research conducted by Hidayati (2016), Lestari (2018), Nasution (2017), and Riani (2017), according to their research results stating that work stress affects turnover intention.

The results of hypothesis testing (H2) have proven that there is an influence of workload on turnover intention. Through the results of calculations, the coefficient value is 0.216 , with a $p$-value of 0.014 . Therefore $0.014<0.05$, Ha is accepted. The results of this study are in line with research conducted by Gabriela et al. (2015), Fitriantini (2020), Riani (2017), their results generally say that workload influences turnover intention.

The results of hypothesis testing (H3) have proven that there is a negative influence of the work environment on turnover intention. Through the results of calculations, the coefficient value of -0.187 with a $p$ value of 0.047 . i Therefore $0.047<0.05$, Ha is accepted, . This research is in line with research conducted by Reza (2017), Riani (2017), Putra (2017), and Anggreini (2019), where their research results state that the work 
environment influences turnover intention.

The results of hypothesis testing $(\mathrm{H} 4)$ have proven that there is an influence of work stress on turnover intention mediated by job satisfaction. Through the results of calculations, the coefficient value is 0.090 , with a $p$-value of 0.035 . Therefore $0.035<0.05$, Ha is accepted, . The results of this study are consistent with previous studies conducted including Dewi (2016) and Prayogi (2019), which states that there is an influence of work stress on turnover intention, which is mediated by job satisfaction.

The results of hypothesis testing (H5) have proven that there is an influence of workload on turnover intention, which is mediated by job satisfaction. Through the results of calculations, the coefficient value is 0.102 , with a $p$-value of 0.044 . Therefore, $0.044<0.05$, Ha is accepted. The results of this study are in line with the results of previous studies, including by Mahaiswari (2015), which states that there is an influence of workload on turnover intention, which is mediated by job satisfaction.

The results of hypothesis testing (H5) have proven that there is an influence of the work environment on turnover intention mediated by job satisfaction. Through the results of calculations that have, the coefficient value is -0.148 , with a $p$-value of 0.035 . Therefore $0.035<0.05$, Ha is accepted, and Ho rejected it. The results of this study concluded that job satisfaction could mediate the relationship of the work environment with turnover intention. The results of this study are in line with the results of previous studies, including Rusdiyanto (2015), Yuda (2017), and Widhiastana (2017), which states that there is an influence of work confusion on turnover intention mediated by job satisfaction.

\section{Conclusion and Recommendation}

\subsection{Conclusion}

Based on the research results described in the previous chapter, the research conclusions are followings:

1. Job stress is proven to have a direct positive effect on the turnover intention at PT. Patria Migas.

2. Workload proved to have a direct positive effect on the turnover intention at PT. Patria Migas.

3. The work environment is proven to have a direct negative effect on the turnover intention at PT. Patria Migas.

4. Job satisfaction is proven to mediate the effect of work stress on turnover intention.

5. Job satisfaction is proven to mediate the effect of workload on turnover intention.

6. Job satisfaction is proven to mediate the influence of the work environment on turnover intention.

\subsection{Recommendation}

Based on these conclusions, the recommendation to be beneficial for PT. Patria Migas as follows:

1. Companies should adjust the ability of employees to provide targets and do not require employees to finish work too quickly because these things make employees feel pressured so that it causes stress when working at the company, which has an impact on increasing their desire to leave the company, and looking for other companies that more fun. Besides, the bosses in the company should first communicate about what tasks will be given to employees, so employees will more clearly respond to the tasks given and will not feel confused about completing these tasks.

2. Companies should not give enough time to complete their work, and try not to work overtime on holidays. These factors can certainly increase the workload felt by employees, which, if it occurs continuously, will have an impact on their desire to leave the company.

3. Every employee always expects a safe and comfortable work environment, both in government companies and in private companies - the high desire of employees to get out of PT. Patria Therefore, companies should always pay attention to the work environment of employees, and make it as comfortable as possible so that employees feel comfortable and safe when working at the company.

4. Job satisfaction felt by employees makes an essential factor for the sustainability of a company. Therefore the company must ensure that employees always feel satisfied when working in the company, so they do not wish to leave the company.

\section{References}

Aamodt G. Michael (2010). Applied Industrial/Organizational Psychology, Belmont, USA: Wadsworth, Cengage Learning.

Afia, Atep. (2013). Tata Tulis Karya Ilmiah. Jakarta : Pusat Pengembangan Bahan Ajar UMB.

Anita, Julia; Aziz, Nasir; dan Yunus, Mukhlis. (2013). Pengaruh Penempatan Dan Beban Kerja terhadap Motivasi Kerja dan Dampaknya Pada Prestasi Kerja Pegawai Dinas Tenaga Kerja dan Mobilitas Penduduk Aceh. Jurnal Manajemen Pascasarjana Universitas Syiah Kuala vol. 2, no. 1, 67-77

Anggreini Silvia, dan Suryalena, (2019). Pengaruh Lingkungan Kerja dan Komitmen Organisasi terhadap Turnover Intention Karyawan (Studi pada Karyawan Alpha Hotel Pekanbaru). JOM FISIP, Vol. 6, edisi II, hal. 1-13. 
Applebaum, Diane, and Susan Fowler (2010). The Impact of Environmental Factors on Nursing Stress Job Satisfaction, and Turnover Intention. The Journal of Nursing Administration, 40(7-8): 323-328.

Basri, M.H, (2017). Pengaruh Stres Kerja Terhadap Turnover Intentions Melalui Kepuasan Kerja Kada CV. Aneka Produksi. Jurnal Ilmu Manajemen, 5(2), 1-7.

Champoux E. Joseph. (2017). Organizational Behavior: Integrating Individuals, Groups, and Organizations, Fifth Edition, Routledge.

Colquitt A. Jason. Lepine A Jeffery Wesson J. Michael. (2017). Organizational Behavior: Improving Performance And Commitment In The Workplace, Sixth Edition, New York: McGraw-Hill.

Dewi Purnama Budiastuti Ayu K, dan Wibawa Artha Made I, (2016). Pengaruh Stres Kerja pada Turnover Intention yang Dimediasi Kepuasan Kerja Agen AJB Bumiputera 1912. E-Jurnal Manajemen Unud, Vol. 5, No. 6, hal. 3560-3588.

Dewi Andi Sofia Putu, dan Sriathi Ayu Agung Anak, (2019). Pengaruh Stres Kerja terhadap Turnover Intention yang Dimediasi oleh Kepuasan Kerja. E-Jurnal Manajemen, Vol. 8 No. 6, hal. 3646-3673.

Dessler, Gary. (2017). Human Resource Management.USA: Pearson.

Febriyanti, Bahirah Mustika \&amp; Faslah, Roni. (2013). Hubungan Antara Beban Kerja Dengan Kinerja Pada Karyawan Balai Permasyarakatan Kelas I Jakarta Selatan (Bapas) di Jakarta Timur. Jurnal Pendidikan Ekonomi Dan Bisnis. Vol 1. No. 2. Hal:104-116.

Firda W., Dheasey A., Amanda M R., MOh. Mukeri W, (2017). Pengaruh Beban Kerja, Stres Kerja dan Motivasi Kerja terhadap Turnover Intention Karyawan PT. Geogiven Visi Mandiri Semarang. Journal of Management. ISSN, III (3), 2502-7689.

Fitriantini Rini, Agusdin, Nurmayanti Siti, (2020). Pengaruh Beban Kerja, Kepuasan Kerja, dan Stres Kerja terhadap Turnover Intention Tenaga Kesehatan Berstatus Kontrak di RSUD Kota Mataram. Jurnal Distribusi, Vol. 8, No. 1, hal. 23-38.

Ghozali, Imam. (2013). Aplikasi Analisis Multivariate dengan Program SPSS. Edisi Ketujuh. Semarang : Badan Penerbit Universitas Diponegoro.

Ghozali, Imam. and H. Latan, (2015). Partial Least Squares: Konsep, Teknik dan Aplikasi Menggunakan SmartPLS 3. 0, Edisi 2. Semarang: Universitas Diponegoro.

Gibson. L. James, Ivancevich M. John and Donnelly, Jr. H. James, and Konopaske Robert (2012). Organizations: Behavior, Structure, Processes, Fourteenth Edition, Mc Graw-Hill

Halimah Tika Nur, Aziz Fatoni, dan Maria Minarsih. (2016). Pengaruh Job Insecurity kepuasan kerja dan lingkungan Keja Terhadap turnover Intention Pramuniaga DI Gelael Supermarket (studi Kasus Pada Gelael Supermarket Superindo Kota Semarang). Jurnal Of Manajemen, Vol. 2, No. 2 Maret 2016.

Harjanti Widiastuti. (2002). Pengaruh Luas Ungkapan Sukarela dalam Laporan Tahunan terhadap Earning Response Coefficient (ERC), Simposium Nasional Akuntansi V, Semarang 5-6 2003.

Harter, J. K., Schmidt, F. L., \& Hayes, T. L., 2002. Business-Unit level Relationship Between Employee Satisfaction, Employee Engagement, And Business Outcomes: A Meta-Analysis. Journal of Applied Psychology Vol. 87: page. 268-79.

Haryono, Siswoyo. (2017). Metode SEM Untuk Penelitian Manajemen dengan AMOS, LISREL dan PLS untuk Penelitian Manajemen. Luxima Metro Media

Haryono Siswoyo, Nur'aini Hanifah, and Mohd Shamsuri Md Saad. (2019). The Mediating Role of Work-Family Conflict on the Effects of Workload, Opcion Journal, Vol. 35 No. 20 p. 832-850. https://www.researchgate.net/publication/333816135_The_Mediating_Role_of_Work_Family_Conflict_a on_the_Effects_of_Workload_Towards_Medical

Heizer Jay, Render Barry, and Munson Chück. (2020). Operations Management: Sustainability and Supply Chain Management (12th Edition), Pearson

Indrayani, I. G.A.P.W, (2012). Peran Mediasi Kepuasan Kerja dan Komitmen Organisasional pada Hubungan Stres Kerja dengan Intensi Keluar Karyawan. Jurnal Bisnis Hospitaliti, 1(1), 1-7.

Joarder, Mohd H. R. Mohmad Yazam Sharif, and Kawsar Ahmmed, (2011). Mediating Role of Affective Commitment in HRM Practice and Turnover Intention Relationship: A Study in a Developing Context. Business and Economics Research Journal, 2(4): 135-158

Lestari Sri Yani Ni Nyoman, (2018). Pengaruh Stress Kerja, Komitmen Organisasi dan Kepuasan Kerja terhadap Turnover Intention. E-Jurnal Manajemen Unud, Vol. 7 No. 6, hal. 3412-3441

Lussier N. Robert and Hendon R. John. (2019). Human Resource Management, Functions, Applications, and Skill Development, Third Edition, Springfield College University of Arkansas at Little Rock, USA: Sage Publication.

Mahaiswari Sri Ag. Sg. A.A. dan Rahyuda Ganesha Agoes, (2015). Peran Stres Kerja dalam Memediasi Pengaruh Kontrak Psikologis dan Beban Kerja terhadap Keinginan Karyawan untuk Keluar dari Organisasi: Studi Pada Sebuah Klinik Kecantikan. E-Jurnal Manajemen Unud, Vol. 4, No. 4, hal. $930-942$.

Mathis L. Robert and Jackson H., John. (2016). Human Resource Management. Cengage Learning 
Nasution Irfan Muhammad, (2017). Pengaruh Stress Kerja, Kepuasan Kerja dan Komitmen Organisasi terhadap Turnover Intention Medical Representative. Jurnal Ilmiah Manajemen, Volume VII, No. 3

Pradana Andika, dan Salehudin Imam, (2013). Analisis Pengaruh Beban Kerja Terhadap Turnover Intention pada Akuntan Publik yang Dimediasi oleh Kepuasan Kerja dan Stress Kerja. Jurnal Fakultas Ekonomi Universitas Indonesia, hal. 1-15

Prayogi Andi Muhammad, Koto Murviana, and Arif Muhammad, (2019). Kepuasan Kerja sebagai Variabel Intervening pada Pengaruh Work-life Balance dan Stres Kerja terhadap Turnover Intention. Jurnal Ilmiah Manajemen dan Bisnis, Vol. 20. No. 1, hal. 39-51.

Putra Dharma Gede Dewa I, dan Utama Mudiartha Wayan I, (2017). Pengaruh Lingkungan Kerja dan Kepuasan Kerja terhadap Turnover Intention di Mayaloka Villas Seminyak, E-Jurnal Manajemen Unud, Vol. 6, No. 9, hal. 5116-5143.

Rivai, Veithzal. \& Sagala, E. J. (2009). Manajemen Sumber Daya Manusia untuk Perusahaan. Jakarta: Rajagrafindo Persada.

Riani Tesi Luh Ni, dan Putra Surya Made, (2017). Pengaruh Stres Kerja, Beban Kerja dan Lingkungan Kerja non Fisik terhadap Turnover Intention Karyawan. E-Jurnal Manajemen Unud, Vol. 6, No. 11, hal. 59705998.

Robbins P. Stephen and Judge A. Timothy. (2018). Essentials of Organizational Behavior, New York, UA: Pearson.

Rusdiyanto, W, dan Riani A. L., (2015). Pengaruh Kepemimpinan Transformasional dan Transaksional terhadap Kepuasan kerja dan Organizational Citizenship Behavior. Jurnal Economia, 11(2), 161-168.

Schuler S. Randal dan Jackson E. Susan (2017). Managing Human Resources, London: Oxford University Press.

Sekaran, Uma. (2017). Business Research Method. 7th Edition, Willey Publisher

Sunyoto, Munandar Ashar. (2001). Psikologi Industri dan Organisasi. Jakarta: UI-Press.

Suwatno. \& Priansa, D. (2011). Manajemen SDM dalam organisasi Publik dan Bisnis. Bandung: Alfabeta.

Widhiastana, N. D., Wardana, M, dan Sudibya, I. G. A, (2017). Pengaruh Lingkungan kerja dan Penghargaan terhadap Kreativitas dan Kinerja Pegawai di Universitas Pendidikan Ganesha. E-Jurnal Ekonomi dan Bisnis Universitas Udayana, 6(1), 223-250.

Wisantyo, Nurmalitasari Indah \& Madiistriyatno, Harries. (2015). Pengaruh Stres Kerja, Disiplin Kerja Dan Kepuasan Kerja Terhadap Intensi Turnover (Studi pada Lembaga Pengelola Dana Bergilir Koperasi dan Usaha Mikro, Kecil dan Menengah). Jurnal MIX Vol. V, No. 1. Hal:54-69.

Yuda, I. B.D.P dan Ardana, I. K, (2017). Pengaruh Kepuasan Kerja dan Stres Kerja terhadap Turnover Intention pada Karyawan Hotel Holiday Inn Express. E-Jurnal Manajemen Unud. 6(10), 5319-5347. 